УДК 780.614.331.083.071.1(477.54)

DOI https://doi.org/10.31723/2524-0447-2020-30-2-29

Алла Олексіӥвна Мельник

ORCID: 0000-0001-5811-8958

кандидат мистецтвознавства,

доцент кафедри оркестрових струнних інструментів

Харківського національного університету мистецтв

імені I. П. Котляревського

4alusik@ukr.net

\title{
ДОСВІД ВЗАЕМОДІЇ СКРИПКОВОГО ТА ДОМРОВОГО ВИКОНАВСТВА (НА ПРИКЛАДІ «ДИТЯЧОГО АЛЬБОМУ» ДЛЯ СКРИПКИ ТА ФОРТЕПІАНО Л. ШУКАЙЛО)
}

\begin{abstract}
Мета статті - узагальнення виконавського і методичного досвіду гри на ладово-споріднених інструментах задля застосування його у навчальному процесі. Методологія дослідження спирається на системно-аналітичний та компаративний методи, що надають можливостей порівняння специфічних для скрипкового та домрового виконавства прийомів звуковидобування та застосування їх в умовах технічного та виразного потенціалу того чи іншого інструменту. Наукова новизна обгрунтування параметрів взаємодії скрипкового та домрового виконавства на матеріалі творів сучасних украӥнських композиторів. Методичний ракурс дослідження проблем виконавської техніки зумовлює дослідницьку новизну актуальних питань сучасної виконавської практики. Висновки. Дослідження спільних прийомів виконавської техніки гри на скрипиі та домрі на прикладі «Дитячого альбому» Л. Шукайло сприяє узагальненню виконавського і методичного досвіду гри на ладово-споріднених інструментах. Вивчення виконавської практики на іншому інструменті допомагає збагатити виражальні засоби власного інструменту. Розуміння особливостей звуковидобування на різних інструментах сприяє адекватному та художньо достовірному відтворюванню на них музичних творів. Шляхом «запозичення» окремих скрипкових прийомів техніки, артикуляції та засобів виражальності відбувається творче взаємозбагачення і розширення виконавських обріїв гри на домрі. Обгрунтування параметрів взаємодії скрипкового та домрового виконавства на прикладі п'єс з «Дитячого альбому» для скрипки і фортепіано Л. Шукайло підтвердило зв'язок між иими інструментами, котрі не часто перетинаються в мистецтві, але, маючи спільну природу й однаковий лад, черпають з надр виражсального арсеналу одне одного певні складники для подальшого творчого розвитку. Враховуючи очевид-
\end{abstract}

(C) Мельник А. О., 2020 
ну ладову спорідненість скрипки і домри, всі п'єси циклу повною мірою можуть бути використані також і в домровому репертуарі (у спеціальних класах скрипки та домри, ансамблевому класі, як допоміжний матеріал з таких дисииплін, як «Педагогічна практика» та «Аналіз педагогічного репертуару» для студентів та викладачів вищих навчальних закладів).

Ключові слова: артикуляція, виконавство, «Дитячий альбом» Л. Шукайло, домра, засоби гри, ладова спорідненість інструментів, скрипка.

Melnyk Alla Oleksiivna, PhD of Arts, Associate Professor at the Department of Orchestral String Instruments of the Kharkiv National I. P. Kotlyarevsky University of Arts

Experience of interaction between violin and domra performance (on the example of "Children's album" for violin and piano by L. Shukaylo)

The purpose of the article is to generalize the performing and methodological experience of playing fret - related instruments for its application in the educational process. The research methodology is based on the systemanalytical and comparative methods, which provide an opportunity to compare the techniques of sound production specific for violin and domro performance and their application in the conditions of the technical and expressive potential of a particular instrument. Scientific novelty - substantiation of the parameters of interaction between violin and domra performance on the basis of the works of modern Ukrainian composers. The methodological perspective of the study of the problems of performing technique determines the research novelty of topical issues of modern performing practice. Conclusions. The study of general techniques of performing technique of playing the violin and domra on the example of "Children's Album" by L. Shukailo contributes to the generalization of the performing and methodological experience of playing the modal-related instruments. Learning how to practice on another instrument helps to enrich the expressive means of your own instrument. Understanding the peculiarities of sound production on different instruments contributes to the adequate and artistically reliable reproduction of musical works on them. By "borrowing" individual violin techniques, articulation and means of expression, creative mutual enrichment and expansion of the performing horizons of playing domra occurs. Justification of the parameters of interaction between violin and domra performance on the example of pieces from the Children's Album for violin and piano by $L$. Shukailo confirmed the connection between these instruments, which rarely intersect in art, but having a common nature and the same order, draw from the depths of each other's expressive arsenal certain components for further creative development. Taking into account the obvious modal relationship of the violin and domra, all the pieces of the cycle can be fully used also in the house repertoire (in special classes of violin and domra, in the ensemble class, as auxiliary material in such disciplines as "Pedagogical practice" and "Analysis of the pedagogical repertoire" for students and teachers of higher educational institutions).

Key words: articulation, performance, "Children's album» by L. Shukaylo, domra, playing techniques, fret relationship of instruments, violin. 
Мельник Алла Алексеевна, кандидат искусствоведения, доцент кафедры оркестровых струнных инструментов Харьковского национального университета искусств имени И. П. Котляревского

Опыт взаимодействия скрипичного и домрового исполнительства (на примере «Детского альбома» для скрипки и фортепиано Л. Шукайло)

Цель статьи - обобщение исполнительского и методического опыта игры на ладово-родственных инструментах для применения его в учебном процессе. Методология исследования опирается на системно-аналитический и компаративный методы, обеспечивающие возможность сравнения специфических для скрипичного и домрового исполнительства приемов звукоизвлечения и применения их в условиях технического $u$ выразительного потенциала того или иного инструмента. Научная новизна - обоснование параметров взаимодействия скрипичного $и$ домрового исполнительства на материале произведений современных украинских композиторов. Методический ракурс исследования проблем исполнительской техники обусловливает исследовательскую новизну актуальных вопросов современной исполнительской практики. Выводы. Исследование общих приёмов исполнительской техники игры на скрипке и домре на примере "Детского альбома» Л. Шукайло способствует обобщению исполнительского и методического опыта игры на ладово-родственных инструментах. Изучение исполнительской практики на другом инструменте помогает обогатить выразительные средства собственного инструмента. Понимание особенностей звукоизвлечения на разных инструментах способствует адекватному и художественно достоверному воспроизводству на них музыкальных произведений. Путем «заимствования» отдельных скрипичных приемов техники, артикуляции и средств выражения происходит творческое взаимообогащение и расширение исполнительских горизонтов игры на домре. Обоснование параметров взаимодействия скрипичного и домрового исполнительства на примере пьес из «Детского альбома» для скрипки и фортепиано Л. Шукайло подтвердило связь между этими инструментами, которые редко пересекаются в искусстве, но, имея общую природу и одинаковый порядок, черпают из недр выразительного арсенала друг друга определенные составляющие для дальнейшего творческого развития. Учитывая очевидное ладовое родство скрипки и домры, все пьесы иикла в полной мере могут быть использованы также и в домровом репертуаре (в специальных классах скрипки и домры, ансамблевом классе, как вспомогательный материал по таким дисциплинам, как «Педагогическая практика» и «Анализ педагогического репертуара» для студентов и преподавателей высших учебных заведений).

Ключевые слова: артикуляция, исполнительство, "Детский альбом» Л. Шукайло, домра, приёмы игры, ладовое родство инструментов, скрипка.

Актуальність теми дослідження. На перший погляд скрипка і домра мають мало спільного. Інструменти різняться за фор- 
мою, способом звуковидобування, а також за власним місцем у музичному мистецтві. Скрипка значно раніше отримала свій сучасний вигляд і набула чималого розповсюдження, а разом $з$ активним становленням інструмента й виконавських скрипкових шкіл розвивався й відповідний репертуар, котрий опрацьовувався століттями. У домри ж, нагадаємо, інша історія. За царським указом від 13 грудня 1649 року, заборона на інструменти відкинула розвиток домрового мистецтва не на одне століття, тоді як скрипці пощастило більше.

У наш час для домри, окрім оригінального репертуару, існує чимало перекладень скрипкових творів. Наприклад, багато обробок творів скрипкового репертуару, серед яких опуси А. В'єтана, Г. Венявського, Б. Сметани, К. Сен-Санса й інших композиторів, зробив для домри відомий виконавець і педагог Б. Міхєєв. Чимало транскрипцій і перекладень, що користуються неабияким попитом у виконавців-домристів, зроблені також В. Івком і Т. Вольською.

Узагальнення виконавського і методичного досвіду ладово-споріднених інструментів та його застосування у навчальному процесі $є$ нагальною потребою сучасної музичної педагогіки, націленої на розвиток навичок гри на домрі й скрипці. Шляхом «запозичення» одне в одного окремих прийомів техніки, артикуляції, засобів виражальності відбувається творче взаємозбагачення i, таким чином, розширюються виконавські обріï${ }^{1}$. Адже чотириструнна домра свого часу виникла саме на основі скрипкового ладу, що своєю чергою дозволило їй піднятись на інший, значно вищий професійний рівень, та 3 розряду оркестрового інструменту перейти у статус сольного, а відтак активно виходити на концертну естраду.

Мета дослідження - узагальнення виконавського і методичного досвіду гри на ладово-споріднених інструментах задля застосування його у навчальному процесі.

1 Свого часу такою практикою серйозно займався Б. Міхєєв, активно використовуючи у своїх розробках численні скрипкові ігрові засоби. Переосмислюючи праці І. Ямпольского й перенаправляючи їх у русло потреб власного инструмента, Б. Міхеєв реалізував можливості скрипкової техніки у своїй системі гам і вправ. Стимулом же у роботі з розвитку тембрових можливостей домри для Б. Міхєєва стала виконавська творчість Л. Когана, різноманітне вібрато якого виконавець спробував відтворити на домрі. Звідси - неоднаковість тремолювання, в результаті чого інструмент отримав «живий» звук, котрого не було раніше. 
Наукова новизна полягає в обгрунтуванні параметрів взаємодії скрипкового та домрового виконавства.

Виклад основного матеріалу. На прикладі п'єс «Дитячого альбому» для скрипки і фортепіано Людмили Шукайло розглянемо методичні напрацювання для одного з інструментів та їхнє застосування в роботі з іншим, порівнюючи способи гри, а також виявляючи різні інтерпретації одного й того самого прийому ${ }^{2}$. Для повного осмислення певного засобу гри будемо враховувати специфіку кожного інструменту. Звичайно, скрипкою домра не стане і навпаки, але можна, порівнюючи виражальні можливості обох інструментів, працювати над збагаченням і розвитком виконавської майстерності.

Неускладнена ритмічно п'єса «Дощик» виконується на відкритих струнах «мі», «ля» $\mathrm{i}$ «ре» прийомом pizzicato, що робить iii дуже привабливою для скрипалів-початківців, котрі тільки-но почали освоєння інструмента. Головне - слідкувати за метричною основою (звичайно, в паузах також рахувати).

У домровому мистецтві, як відомо, існує три способи виконання pizzicato, а саме: великим пальцем правої руки вниз (в.п.); середнім пальцем правої руки (с.п.) та демпферне pizzicato. Виконання великим пальцем додає звучанню об'єму та глибини. Середнім пальцем pizzicato виконується за умов, коли з тих чи інших причин незручно використовувати великим або ж якщо цього потребує драматургія твору, наприклад, є потреба у полегшеному звуковидобуванні чи більш конкретній характеристиці виконання акордів (приміром, виразніше має звучати саме верхній голос). Демпферне ж pizzicato - виключно колористичний, тембровий прийом на кшталт скрипкової сурдини. Отже, звук, що отримаємо у результаті використання демпферного pizzicato, буде неяскравим, «засурдиненим». Для домри існує чимало оригінального репертуару, і композитори зазвичай вказують, яке саме pizzicato має бути. Відповідно, педагог-скрипаль, маючи обі-

2 Авторка збірки - Заслужений діяч мистецтв України, харківська композиторка Людмила Шукайло. Кілька десятків років поспіль Людмила Федорівна викладає музично-теоретичні дисципліни в Харківській середній спеціалізованій музичній школі-інтернаті. Серед творчого доробку - численні симфонічні, камерні, фортепіанні та хорові твори, багато різноманітної, зокрема, інструментальної музики для юних виконавців. 
знаність стосовно домрової специфіки, 3 метою розвитку творчого уявлення може запропонувати учневі проекспериментувати $з$ емоційним наповненням одноманітного прийому («суворо», «мрійливо», «легковажно», «весело» тощо).

Зрозуміло, що у запропонованій п’єсі pizzicato не конкретизоване, тому можливо рекомендувати виконувати твір тим чи іншим його різновидом поодинці або сполучати їх. Наприклад, почати виконання перших чотирьох тактів pizzicato великим пальцем, наступні 4 виконати середнім, останні ж шість тактів - демпферним. Медіатор принципово не застосовувати.

Таким чином, з методичного погляду користь виконання п'єси полягає у можливості вивчення та практичного застосування скрипкового pizzicato, а також засвоєння всіх трьох різновидів домрового pizzicato у початківців.

П'єса «Периі кроки» виконується агсо (смичком). На початковій стадії вивчення можна звернутися до вже знайомого 3 попереднього твору прийому гри pizzicato (так буде легше засвоїти нотний текст), а вже згодом взяти смичок (медіатор). Із застосуванням смичка перед учнем-скрипалем виникають завдання грамотного його розподілення, відповідно, й адекватного звуковідтворення.

У домриста ж на початку вивчення постає завдання освоєння удару вниз ( / ) та відтворення правильного ритму. Наступний етап передбачає освоєння тремолювання - одного 3 основних та найскладніших засобів гри - часте чергування ударів униз та вгору ( / \), що виконується передпліччям правої руки. Кисть при цьому залишається вільною, тоді як у скрипковому виконавстві під час використання цілого смичка беруть участь всі частини руки. У останніх чотирьох тактах автором вказане посилення та послаблення звуку $(<>)$, відповідно, виникає необхідність відтворення нюансів. Скрипаль посилює та зменшує натиск тростини смичка на струну, а домрист же трансформує звучання завдяки збільшенню або зменшенню амплітуди тремоло. Можна також змінювати положення правої руки: при крещендуванні змістити руку на гриф, а на diminuendo - в бік підставки, що тембрально додасть відчуття зміни динаміки.

Протягом усієї п’єси «Танок ведмежат» витримується нюанс г, що цілком відповідає образному наповненню твору. На початку в партії соліста передбачається чіткий 
уривчастий штрих staccato: вісімками (такти 3-4 та 7-8), що виконується щільним (враховуючи нюанс) швидким коротким рухом смичка ближче до колодки, де добре допомагає вага руки. У тт. 5-6 та 9-10 четвертні тривалості слід грати всім смичком штрихом dŭtashŭ. Нота 3 акцентом виконується швидким рухом смичка вниз з міцною атакою звука на початку штриха.

У домриста під час виконання штриха staccato залежно від темпу й нюансу може використовуватись удар вниз ( / ) або перемінний удар ( / \). У цьому разі найкраще застосувати удар униз ( / $)^{3}$. Вказані для скрипалів у перших тактах напрями руху смичка вниз-вгору для домристів не є актуальними (виконується одним і тим самим штрихом - униз ( / ).

Акцент $($ тт. 6,10) виконується тремоло. Якщо під час виконання dütashŭ у п'ятому такті скрипаль використовує більшу частину смичка, то у домриста означений штрих, враховуючи довжини (четверті), здійснюється ударом униз ( / ) і більшою частиною фаски медіатора (котрий глибше занурюється у струну).

Окреме завдання - подвійні ноти. У цій п'єсі вони дуже зручно розташовані на відкритих струнах, що за відсутності текстових завдань у лівій руці дозволить виконавцю приділити належну увагу труднощам у правій. Окремим завданням буде однаково добре озвучити дві ноти водночас, для чого треба рівномірно розподілити тиск на струни.

Для домристів гра по двом струнам водночас не створює особливих перешкод, навіть одночасна гра по чотирьом струнам не буде надто складною і стане хорошим стимулом для звільнення виконавського апарату. Зазначимо, що окремі викладачі починають навчання саме 3 такого прийому гри. Звуковий шум, шо утворюється в результаті, забавляє маленьких учнів та водночас не обмежує м'язову свободу. У цьому разі певні рухові обмеження існують, тому що використовуються лише дві внутрішні струни. Слід також звернути увагу на вільне падіння передпліччя вниз із урахуванням двох струн

3 Загалом у домровому мистецтві виконання штриха staccato передбачає застосовування лише кінчика медіатора, але враховуючи характер і динаміку, площа використання медіатора збільшується за збереження уривчастого звучання. Слід також враховувати спосіб виконання без замаху руки, натомість підготовленим медіатором із положення «зі струни». 
3 положення готового медіатора (зіграти дві ноти, відчути поріг верхньої струни «мі»).

У п’єсі «Хто там іде?» композитор пропонує використати колористичний засіб гри - col legno - ударом тростини смичка по струнах (тт. 3-4 і тт. 7-8). Враховуючи нешвидкий темп твору і те, що виконання col legno випадає на озвучування квінти на відкритих струнах «ре» і «ля» і не потребує участі лівої руки, на шляху опанування вищезазначеного прийому не має бути особливих перешкод.

Загалом п’єсу можна рекомендувати для освоєння струни «ре» у першій позиції для обох інструментів. Засіб col legno у домровому виконавстві із зрозумілої причини не використовується, отже, потребує адекватної заміни. Можливо спробувати декілька різноманітних варіантів. Наприклад, правою рукою грати по відкритих струнах і водночас відстукувати лівою по панцирю або корпусу інструмента вказаний ритм, наслідуючи таким чином стук дерев'яної частини смичка по струнах. Також можна, заглушивши лівою рукою всі струни, вистукувати ритм медіатором по панцирю, не озвучуючи ноти. Засіб col legno, що у цій мініатюрі зустрічається двічі, можна комбінувати.

У п’єсі «Набридлива муха» маємо завдання засвоїти дубльштрих, коли кожна нота повторюється кілька разів на різні напрямки руху смичка. Основне, за чим потрібно слідкувати, - тверда координація лівої і правої рук, а саме збіг зміни ноти у лівій руці із ії чітким виконанням смичком.

Що стосується домристів, то питання координації також має у цій мініатюрі першочергове завдання. Його вирішення ускладнюється рухами правої руки, бо ритмізоване тремоло повинно виконуватися кистьовими ударами. Такий вид тремолювання можна назвати spiccato. У результаті звуковидобування відповідне звучання має бути чимось середнім між тремолюванням і перемінним штрихом.

Мелодична основа п’єси «Дзига» побудована на секундових зворотах. Примхливий характер відтворено шляхом сполучення штрихів legato й staccato, акцентуванням слабкої долі водночас з мелодичними стрибками на кварту, квінту, октаву, нону. Таким чином досягається певний характерний ефект кружляння дзиги та її постійного завалювання на один бік.

Запропонована скрипкова артикуляція для виконання на домрі не $є$ актуальною. Ритмічна група дві шістнадцятих i 
вісімка виконується медіатором, а саме перемінним ударом (тт. 3-5, 7, 9). Група 3 двох восьмих тривалостей - ударом униз, незалежно від того, стоїть над ними staccato чи артикуляційна ліга. Четвертні й половинні тривалості виконуються tremolo. Четвертні ноти позначені акцентом, що й визначає вибір засобу гри в сторону тремолювання. Зміна удару на tremolo також передбачає відповідне акцентування. Збіг виконавських засобів у скрипки й домри відбувається лише у кінці п'єси - з'являється дубль штрих (рух руки - нота) - на одну вісімку -2 удари, у скрипки - два штриха.

Авторський задум передбачає виконання мініатюри «Перекличка (дует)» на двох інструментах. У домровому варіанті можливе використання одного інструмента у разі, якщо виконавець має більш розвинену попередню підготовку. Труднощі можуть 3'явитися лише у другій половині третього такту. Їх можливо уникнути шляхом підняття нижнього голосу на октаву вгору, у такому разі п’єса буде потребувати виконавської редакції. Враховуючи темп виконання, визначаємось у виборі штриха. Основним штрихом розуміємо удар медіатором униз на четвертних нотах, а вісімки граємо перемінним ударом. Подвійні ноти у двоголоссі також рекомендовано грати ударом. Винятки складають половинні ноти з крапкою, котрі мають бути виконані tremolo. На tremolo слід також виконувати і заключний такт твору. У скрипковому варіанті для одного інструменту також потрібна редакція. Наприклад, слід спростити фактуру у третьому такті, щоб уникнути децими та відмовитися від виконання прими у т. 9.

У мініатюрі «Гавот» спостерігається різноманітна скрипкова штрихова артикуляція - portato, legato, staccato під лігою. Для домри - можливе сполучення tremolo й spiccato (перемінний удар або удар вниз). Редакція у такому разі повинна орієнтуватися на скрипкове виконання й бути спрямована на те, щоб не спотворити, а навпаки, достовірно відтворити жанрові особливості скрипкової версії. Staccato, наприклад, можна виконувати ударом вниз; сполучення portato-legato - тремоло й зняттям ударом вгору. Таким чином, можливе максимальне наближення до відтворення скрипкового виконання засобами, якими оснащений домрист.

Згідно з авторською ремаркою п’єса «Старовинний замок» передбачає дуетне виконання. Як і попередні приклади п'єс для двох виконавців, цю мініатюру також можна спробувати 
запропонувати більш розвиненим учням для сольного виконання. У такій ситуації не рекомендується виконувати приму у т. 5 і тт. 19-20 у зв'язку з надмірно широким аплікатурним розташуванням у першій позиції, якісне подолання якого не завжди під силу навіть зрілому виконавцеві.

У домровому варіанті вся п'єса виконується прийомом tremolo. Якщо передбачається iї виконання solo, то доцільно буде повчити кожен голос окремо.

При виконанні на домрі «Сонатини» засоби й штрихи обираються якомога ближче до скрипкових. Виконувати staccato найкраще прийомом униз, а лігу за можливості виконувати на tremolo. Наприклад, т. 14 слід завершити ударом униз, а далі закінчити фразу на tremolo. Аплікатура, що вказана для скрипки, може бути використана й для домри; тт. 44, 46 для скрипки рекомендується грати дубльштрихами. Домристам також можна використати цей штрих (або ритмізоване tremolo).

Систематизуємо виконавські завдання по кожній п'єсі циклу та виокремимо головне, що складає навчальне спрямування.

У п’єсі № 1 «Дощик» робота спрямована на засвоєння скрипкового pizzicato та різновидів домрового pizzicato.

У п’єсі № 2 «Перші кроки»- виконання смичком та освоєння тремолювання на домрі.

Виконавське завдання у п’єсі № 3 «Маленьке каченя» робота скрипаля над технікою правої руки (розподіл смичка), для домриста - сполучення штрихів удару вниз ( / ) і тремоло.

Урізноманітнення нюансування - це завдання при виконанні п’єс №№ 2 та 3, а також № 4 «Танок ведмежат».

В № 5 «Я стрибаю на батуті» - основним є виконання штриху staccato (у рухливому темпі) та перекид смичка (руки 3 медіатором через струну).

П’єса № 6 «Хто там іде?» рекомендується для освоєння струни «ре» у першій позиції для обох інструментів.

П’єса № 7 «Шкільний дзвоник» - знайомство та вивчення третьої позиції для обох інструментів.

Головним завданням у п’єсі № 8 «Колискова» стане рівномірний розподіл смичка у роботі над кантиленою та над тремоло звуків у домристів.

Першочергове завдання для скрипалів і домристів у п'єсі № 9 «Набридлива муха» - це тверда координація лівої і пра- 
вої рук, а також потреба освоїти дубль-штрих на скрипці, а ритмізоване тремоло - на домрі.

У п’єсі № 10 «Прощавай, садочок» основним є штрих легато у скрипаля, у домриста - виключно легато-тремоло.

П’єси № 13 «Перекличка», № 15 «Арія» та № 19 «Старовинний замок» написані для ансамблевого виконання: №№ 13 та 19 - для дуету, № 15 - для ансамблю скрипалів (домристів).

У п’єсах №№ 14, 15 та 19 основним штрихом виконання для скрипалів є легато, для домристів - тремоло.

Виконавське завдання у процесі виконання п’єси № 17 «Сумний наспів» - це робота над розподілом сили звуку в синкопованому ритмі, а також над фразуванням.

У мініатюрі № 18 «Гавот» першочерговим виконавським завданням $є$ застосування різноманітної штрихової артикуляції для скрипки - портато, легато, стаккато під лігою, а для домри - тремоло й spiccato.

У п’єсах № 21 «Листок 3 альбому» та № 23 «Осіння пісня» основне завдання для скрипалів і домристів полягає у відтворенні максимально цілісної, безперервної мелодії та виразної кантилени.

У п’єсі № 24 «Вічний рух» основна виконавська складність для домриста - зміна дубль-штриха на перемінний удар.

Висновки. Дослідження спільних прийомів виконавської техніки гри на скрипці та домрі на прикладі «Дитячого альбому» Л. Шукайло сприяє узагальненню виконавського i методичного досвіду гри на ладово-споріднених інструментах.

Вивчення виконавської практики на іншому інструменті допомагає збагатити виражальні засоби власного інструменту. Розуміння особливостей звуковидобування на різних інструментах сприяє адекватному та художньо достовірному відтворюванню на них музичних творів. Шляхом «запозичення» окремих прийомів техніки, артикуляції, засобів виражальності відбувається творче взаємозбагачення і розширення виконавських обріїв.

Обгрунтування параметрів взаємодії скрипкового та домрового виконавства на прикладі п’єс з «Дитячого альбому» для скрипки і фортепіано Л. Шукайло підтвердило зв'язок між цими інструментами, котрі не часто перетинаються в мистецтві, але, маючи спільну природу й однаковий лад, черпають 3 надр виражального арсеналу одне одного певні складники для подальшого творчого розвитку. Враховуючи очевидну ладову 
спорідненість скрипки і домри, всі п’єси циклу повною мірою можуть бути використані також і в домровому репертуарі, у спеціальних класах скрипки та домри, ансамблевому класі як допоміжний матеріал 3 таких дисциплін, як «Педагогічна практика» та «Аналіз педагогічного репертуару» для студентів та викладачів вищих навчальних закладів.

\section{СПИСОК ЛІТЕРАТУРИ}

1. Євдокімов С. Скрипкове виконавство: шлях від початківця до віртуоза: навчальний посібник. Харків : ХНУМ ім. І. П. Котляревського, 2007. 128 с.

2. Круглов В. Школа игры на домре. Москва : Пробел-2000, 2003. $245 \mathrm{c}$.

3. Лысенко Н., Михеев Б. Школа игры на четырёхструнной домре. Київ : Музична Україна, 1989. 151 с.

4. Лысенко Н. Методика обучения игре на домре. Київ : Музична Україна, 1990.91 с.

5. Шукайло Л. Дитячий альбом для скрипки та фортепіано [ноти]. Київ : Мелосвіт, 2013. 36 с.

\section{REFERENCES}

1. Evdokimov, S. (2007). Violin performance: the path from beginner to virtuoso: textbook. Kharkiv: KHNUM I. P. Kotlyarevsky [in Ukrainian].

2. Kruhlov, V. (2003). School of domra's playing. Moscow: Probel-2000 [in Russian].

3. Lysenko, N., Mikheev, B. (1989). School of playing the four-string domra. Kiev: Muzychna Ukraina [in Russian].

4. Lysenko, N. (1990). Teaching method playing on domra. Kiev: Muzychna Ukraina, 1990. [in Russian].

5. Shukailo, L. (2013). Children's album for violin and piano [notes]. Kyiv: Melosvit, 2013. [in Ukrainian]. 